\title{
A reutilização da água - Mais uma chance para nós
}

\author{
Autor: Luiz Augusto Rodrigues da Luz
}

$\mathrm{O}$

título adotado pelo autor não pode ser considerado como um

chamamento a uma obra que realmente trate do reuso de água e os aspectos técnicos que devem ser considerados para a aplicação de métodos científicos e tecnologias adotadas no Brasil e no mundo. Portanto, quanto à reutilização da água, não há nada de novo ou pelo menos prático. É um livro leve e fácil de se ler, onde a dedicação e competência do autor no trabalho de pesquisa e coleta de dados, bem como, a proposição de ações que o mesmo apresenta sevem para fazer com que o leitor se envolva com o clima de crítica muito mais política e social, dominante no livro, que com aquilo que o título insinua: Reutilização da Água. A recomendação para leitura vai então ser direcionada para quem deseja conhecer o assunto de forma preliminar e informativa, sem se dedicar a avaliação da própria metodologia adotada na redação, pois, o autor, muitas vezes, assinala conceitos pessoais como verdades e cita indiretamente especialistas que não identifica mais que atestam, segundo o autor, suas próprias opiniões sobre aquecimento global, escassez de água, privatização e gestão de recursos hídricos, tudo, sem apresentação de embasamentos técnicos. Por tudo isso, o valor do livro pode estar na capacidade que ele tem de induzir a discussão, incentivar o debate e permitir que o leitor possa interagir com o autor via a aplicação do contraditório.

A estrutura do livro apresen-

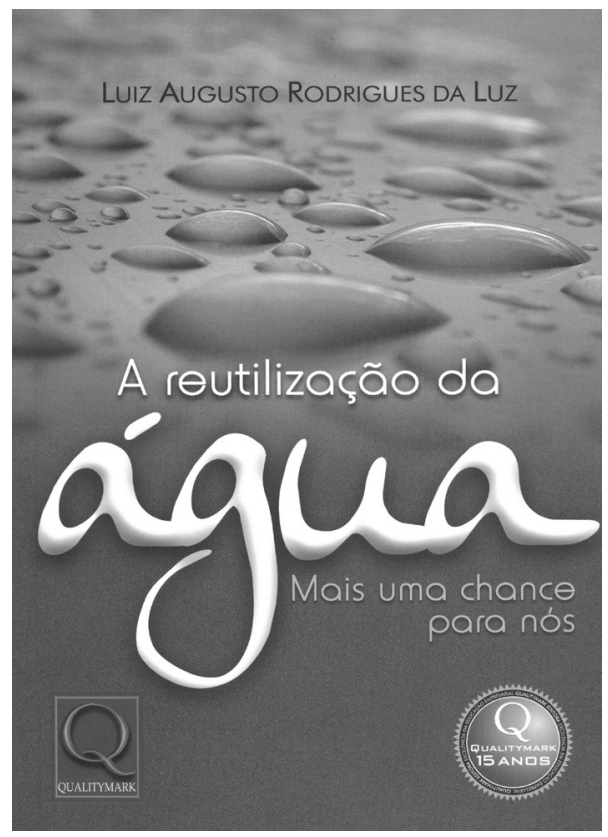

Brasil e no mundo, apresentando casos de desastres ambientais e problemas causados por má gestão de recursos hídricos e do meio ambiente. Fala também sobre legislação, águas subterrâneas, poluição, ciclo hidrológico e a situação da água como fonte de saúde e desenvolvimento;

Capítulo 3 - A Água no Espaço Pára ou Gera Crise Aqui na Terra? Neste capítulo há uma apresentação de estudos realizados pela NASA National Aeronautics and Space Administration e pela ESA - European Space Agency, tratando da disponibilidade de água em Marte e o autor, faz análises e avaliações sobre o futuro da água na Terra;

Capítulo 4 - O Que Estamos Fazendo nas Empresas. Neste caso o autor apresenta aquilo que, segundo ele, vem sendo realizado em algumas empresas para reutilizar e reciclar resíduos sólidos ou líquidos, discorrendo também sobre o uso das águas pluviais, sobre a legislação aplicada ao reuso, sobre as medidas para solucionar os problemas da poluição das águas e sobre o que é um sistema de gestão ambiental;

Capítulo 5 - O Desacordo Está Efetivado. Então Existe Água Nova. O autor mergulha na utilização de equações químicas para mostrar que há uma quantidade de água sendo criada a partir "da reação global de hidrocarbonetos (não só dos alcanos).Sendo assim, essa quantidade de água produzi da é somada ao fenômeno hidrológico";

Capítulo 6 - Dicas para se Economizar Água. Como o título sugere são apresentadas informações sobre como contribuir para que ta: Agradecimentos, Prefácio, Prólogo, Introdução, Seis capítulos, Conclusão, Glossário/Siglário, Referências Bibliográficas e o Poema das Águas, totalizando 125 páginas. Os destaques ficam então por conta dos capítulos adiante comentados:

Capítulo 1 - A Origem da Água e a Dessacralização da Natureza: se apresenta aqui uma verdadeira viagem pela história da Terra, a evolução e suas teorias, bem como aquilo que o autor chama de dessacralização da Terra para mostrar como o homem agride a natureza e conseqüentemente a água, culminando com uma proposição sobre o manejo da água;

Capítulo 2 - Água - Benefício ou Problema? No mais longo capítulo do livro, o autor avalia os impactos da forma como a água é utilizada no se mitiguem os danos causados aos recursos hídricos, como também, as maneiras que podem ser adotadas para economizar água nas resi dências e empresas, desde a elaboração de projetos e a construção, e fornece também medidas preventivas gerais para empresas e residências. Por fim, faz comentários sobre a responsabilidade dos Governos.

O autor, na conclusão, chama atenção para a contribuição que pretendeu dar no que se refere ao entendimento da importância da água para a vida na Terra e conclama a todos os leitores a se engajarem na luta pela conservação e proteção da água.

\section{Comentário elaborado por Álvaro José Menezes da Costa Coordenador da coluna Livros: Cícero Onofre de Andrade Neto}

A sessão "Livros", que a cada edição traz resumos comentados sobre livros de interesse na área, tem como principal objetivo permitir que o leitor, de forma rápida, se atualize e conheça o que há disponível no mercado editorial. As contribuições deverão ser encaminhadas para: resa@abes-dn.org.br 